\title{
Civil-Military Relations in China: Party-Army or National Military?
}

\author{
David Shambaugh
}

\begin{abstract}
This article examines the changing dynamics of relations between the Chinese Communist Party (CCP) and the People's Liberation Army (PLA). It argues that while the PLA remains politically loyal to the CCP, there is evidence of important changes in the institutional relationship between the two institutions. The partyarmy relationship is no longer as intertwined and symbiotic as it has historically been; rather, this article argues that there is evidence of a 'bifurcation' between the two. The catalysts for this change have been the professionalization and relative depoliticization of the military, as well as the leadership transition in the CCP. These changes raise important and central issues for the future of Chinese politics.*
\end{abstract}

\section{Introduction}

As the Chinese Communist Party (CCP) has had to adapt to changes in Chinese society during the reform period and in the wake of the collapse of communist party-states elsewhere, ${ }^{1}$ it has also had to adjust and renegotiate its relationship with other key organs of state power. ${ }^{2}$ Among these has been the party's relationship with the People's Liberation Army (PLA). Yet the renegotiated relationship has occurred not just between party and army, but also between both and a third party: the state. Since the mid-1990s there has been an evident, if subterranean, three-way struggle over the jurisdictional control of the military being played out among the army, party and government in China. The army has sought greater autonomy from party control so as to better pursue its redefined professional missions, which has forced the party to redefine and adjust its instruments of control over the army, while the government (state) has tried to increase its own jurisdictional control over the armed forces while continuing to delineate its sphere of responsibilities distinct from the party (dang-zheng fenkai).

While this subterranean struggle has been evident to careful observers, because of their inherently political and highly sensitive nature, these changes have been only incremental and subliminal. They rarely spill over into the public domain. No explicit and radical restructuring 
of party-army relations has been undertaken. To do so would call into question the very legitimacy of the CCP as a ruling party. The longstanding Maoist paradigm that the 'party controls the gun' remains standard mantra (tifa) and is, in fact, still the case. We certainly cannot claim that the army has gained its 'independence' from party control. The army would certainly follow orders from the party leadership to use force against external threats and most likely against internal ones as well. The army does remain loyal to the party. There is no danger of a military coup d'état of the army against the party, as is often the case in other one-party authoritarian states. Nonetheless, as this paper argues, there do exist growing signs of 'bifurcation' between these two institutions - which cumulatively add up to a significant, and ongoing, redefinition of the institutional and jurisdictional relationship between the CCP and PLA.

\section{From Party-Army to Civil-Military Relations}

Western analysts of the PLA have long considered it more appropriate to use the term 'party-army relations' rather than the more generic term 'civil-military relations,' as commonly used elsewhere in the world. This was so because of a number of important historical considerations that set the PLA's relationship to the ruling Chinese Communist Party apart from its counterparts in other countries. It was recognized that militaries in communist political systems are intrinsically and inherently different from other one-party authoritarian systems, to say nothing of militaries in democratic polities.

In communist party-led political systems (the People's Republic of China included) the military is an institutional and armed instrument of the party. Communist militaries do not exhibit the degree of 'corporate' identity and political autonomy characteristic of Western militaries. This is so for a number of reasons. The first is that the act of seizing and maintaining - power is usually a violent one, in which armed force is used for political ends. This fact intrinsically places the military (and other coercive security services) in the position of being an armed adjunct of the party rather than as an autonomous force charged with defending the nation against external threat. ${ }^{3}$ As such, a communist military's national security mission is a dual one - to be used against both internal and external enemies. Moreover, communist militaries (including the PLA) are institutionally penetrated by the ruling communist party - particularly through a network of political commissars, party committees and other mechanisms. This is the essence of Leninist par- 
ties - to penetrate institutionally all key organs of state and society. Yet it is not simply an issue of zero-sum penetration, but also a positive sum relationship whereby the army is given an important stake in the ruling party. One way this is done is to co-opt the military elite into the party elite. In the PLA, all officers above the rank of Senior Colonel are party members. This is even more evident at the top of the political system through the 'interlocking directorate,' where there is usually a high percentage of senior serving military officers on the party's elite organs (the Central Committee and Political Bureau), with many more senior party officials having previously served in the armed forces (trading their uniforms for civilian garb but maintaining close factional ties with military elites). In such communist militaries, 'political work' and ideological indoctrination of the officer corps and the rank and file are prominent and occupy considerable time (net time not spent in training).

In short, in communist militaries (including the PLA), there exists an essential symbiosis between the army and ruling communist party. Sometimes this symbiosis is reflected in party attempts to assert greater control over the military, while at other times communist militaries have become more politically assertive vis-à-vis the ruling party - although in such systems, because of the essential symbiosis, militaries do not engineer coups d'état against their ruling parties (although they may become involved in intra-party factional manoeuvring).

Such a model of party-army relations was wholly applicable to China until the second half of the 1990s, although I argue in this paper that it has been only partially applicable since that time. For a variety of reasons and judged by a variety of indicators, the relationship between the PLA and the CCP is evolving significantly and possibly transforming fundamentally. To be sure, it is still a party-army in important respects, but a number of the criteria noted above no longer characterize the CCPPLA relationship. The military's mission today is almost exclusively external, to protect national security rather than internal security (the People's Armed Police has been created to take primary responsibility for this mission). Importantly, the 'interlocking directorate' has been completely broken by generational succession, whereby not a single senior party leader today possesses a single day of military experience and, currently, only two senior PLA officers in the High Command (Generals Chi Haotian and Wang Ruilin) have any significant experience in high-level politics - a trend that will become more pronounced with the transition to the 'fourth generation' CCP leadership. The party-army elite has clearly become 'bifurcated' from each other. 
Another change is that the criteria for career advancement in the PLA are no longer as dependent on political factors. Senior PLA officers from the Central Military Commission down to Group Army commands are now promoted on meritocratic and professional criteria, while political consciousness and activism count for very little. The officer corps is becoming increasingly professional in classic Huntingtonian terms. Indeed, recruitment into the PLA is now based almost exclusively on technical criteria. The role of the ideology is virtually nil and political work has declined substantially; concomitantly the General Political Department's mission has become more oriented to providing welfare for soldiers and their families than to indoctrinating them. Time formally spent in political study (approximately 30 percent in the past) is now spent in training. Political work (zhengzhi gongzuo) itself is now much more oriented towards welfare, morale and living issues than to ideological indoctrination. This is also true of curriculum content in institutions of professional military education (PME), now mandatory for all officers above the division level. Officers spend time learning the intricacies of doctrine, strategy and tactics rather than communist doctrine. With commercial divestiture, time formerly spent in business is now also spent increasingly in training, as PLA units have been ordered to divest themselves of their commercial holdings. The military is also now subject to control by a large number of formal laws and regulations, instead of the informality and personalization of command and control. The State Council and Ministry of Finance are now exerting much stronger control over the PLA budgeting process, and at least on paper (the National Defence Law) the President and National People's Congress possess command and oversight responsibilities over the PLA.

Accordingly, for these reasons, it is now more analytically appropriate to consider civil-military rather than party-army relations in the PRC. The driving catalyst for all of these changes has been the professionalization of the armed forces. ${ }^{4}$ To be sure, as is argued below, this evolution is ongoing and incomplete. The former model has not, and is not likely to, replace completely the latter model. Yet, along a number of criteria, it does seem clear that the PLA is moving away from its traditional communist institutional ethos into a new stage of limited autonomy from the ruling party.

Theoretically, in terms of the comparative study of civil-military systems, this new stage may also be viewed as the intermediate stage in a transition from a party-army to a 'national army'. China and the PLA are clearly not there yet, and it is very questionable whether a national 
army can exist within the context of a political system dominated by a single, ruling communist party. Yet there have been, and continue to be, subterranean discussions in China and the PLA about greater state control of the military, a military that serves the nation and not just the ruling party, and a military controlled by civilian rule and governed my legislative oversight. As if to put a fine point on the sensitivity of such considerations, there has been a series of ongoing condemnations of such 'bourgeois' concepts in the party and military media from time to time. It is clearly a sensitive issue that cuts right to the core of PLA identity and CCP legitimacy, if not the efficacy of the PRC itself.

Is it feasible to have a national army in a Leninist system? Or can such a military only exist in a democratic system? Given the evidence of economic and educational reforms in China, to take but two issue areas, it is not inconceivable that a hybrid relationship of a professional national military could co-exist with a ruling communist party, but within a framework of state and legislative control. Yet, on the other hand, many of the elements necessary to proclaim the PLA a 'national army' seem anathema to the CCP and its rule. For example, it would require at least the following: a 'real' Ministry of National Defence (not the hollow shell of the MND at present); a civilian Minister of Defence; presidential chairmanship of the Central Military Commission; thorough control of military by the state President, National People's Congress, and State Council; a series of established laws and procedures governing the use of force and mobilization of the military; strong legislative oversight of the armed forces; complete budgetary control over the military by the legislature and no extra-budgetary revenue; and no political content in professional military education. Judged on these criteria, it is clear that the PLA and China are a long way from becoming a national army, yet there are discussions and tendencies in this direction taking place in China and the PLA today.

To understand how the PLA and the CCP got to this stage, it is appropriate to understand some historical context, before considering the implications of recent changes that have occurred in civil-military relations.

\section{Historical and Comparative Considerations}

Any consideration of civil-military relations in China as it enters the twenty-first century must proceed from clear cognizance of the past. Over the last century, individual military actors and the military as an institution have played key and active roles in the Chinese regime and nation. This has taken a variety of forms over time, but the military has 
never been fully isolated from the political arena. Both military and party elites have viewed military involvement in politics, domestic security, society and even commerce as legitimate. While the political involvement of the Chinese military is distinct from the Western tradition of military corporatism and separation from the political arena (based on the Ottoman, European and American experiences ${ }^{5}$ ), it is hardly unique among developing or socialist countries. Many post-colonial and developing nations have experienced sustained military rule and praetorian intervention, ${ }^{6}$ while most former communist party-states were based on the 'interlocking directorate' of party and military elites and the penetration of the military and security services by party control mechanisms. ${ }^{7}$ More recently, scholarly attention has been paid to the military's withdrawal from politics and subordination to civilian control in the process of the transition to democracy across the developing and industrializing world. ${ }^{8}$ An interesting literature has also begun to address civil-military relations in the Chinese context of a democratizing Taiwan. ${ }^{9}$ Scholars specializing in post-1949 Chinese military politics would do well to tap into all of these studies, as the PLA shares many commonalities with these other cases. As professionalism and corporate identity rise in the PLA, and greater efforts are made to subject the military to state control, comparing other national experiences will be increasingly pertinent to understanding the future evolution of the PLA. ${ }^{10}$

Understanding the interrelationship among party, state and army in the PRC today must also recognize several long-standing and unique features of civil-military relations in China historically. Throughout the past century, from the late imperial to the post-Deng era, the Chinese military has played an active role in the political and economic life of the nation (even if soldiers, along with merchants, were at the bottom of the Confucian social order). Key late-Qing reformers, such as Li Hongzhang, were military men who believed that the path to 'wealth and power' (fu-qiang, the cardinal tenet of all subsequent Chinese elites) lay in mastering military technologies and building a strong self-defence capability in order to rebuff foreign encroachment and regain China's unity and lost greatness. Li's policy of 'building shipyards and arsenals' and dispatching students to Europe and America to study in defence colleges and scientific institutes bespoke this bias. To be sure, heated debate existed among Qing elites over the wisdom of this policy - some argued that it was a distorted path to development which disproportionately emphasized military modernization over the need for 
a more comprehensive technological base; others opposed the inherent 'Westernization' and cultural contamination implicit in the strategy; while still others believed that the 'sources of wealth and power' were less technological and more civic, political and intellectual in nature. These debates have resonated over the past century, and echoes of them are still present today.

After the republican revolution of 1911, military elites remained prominent in the new government (not the least of which was General Yuan Shikai, who became the first President of the republic) and an emphasis on building a modern military remained a high priority. With Yuan's death in 1916, the ensuing constitutional crisis and failure of the new regime to consolidate national power, China slipped into a prolonged period of territorial division, national fratricide and rule by an ever-shifting variety of military warlords. This bloodthirsty period was halted only when force was met with force during Generalissimo Chiang Kai-shek's 1928 Northern Expedition, which united the country under the civil-military rule of the Nationalist party and army (Kuomintang and Kuominjun). The new KMT elite during the 'Nanjing decade' (192737) contained a large proportion of military officers, secret police and intelligence operatives - many trained under Chiang at the Whampoa Military Academy and in military and paramilitary institutions in Germany and the Soviet Union. This regime would only become more militarized following the outbreak of the Sino-Japanese War in 1937. ${ }^{11}$

Meanwhile, in the communist-controlled base areas of China's interior, a similar militarily dominant political regime was also taking shape. The Red Army was born not only of necessity, out of the need literally to fight for survival against Japanese and KMT forces, but also as a result of the strong Soviet and German influences on the politicization of the military and militarization of the party. Throughout the revolutionary period an essential symbiosis existed between party and army in pursuit of state power. ${ }^{12}$ The Chinese Communists' ultimate victory in 1949 was at least as much a military as political one - as the Red Army fought the Japanese invaders and defeated Kuomintang forces on the battlefield, pacified the countryside, and occupied the cities. ${ }^{13}$ So closely intertwined were the institutions of party and army historically, that one must recognize the unique and often dominant roles that the military has played, as a normative and institutional actor, in the life of the nation. As Chairman Mao astutely observed, 'Political power grows out of the barrel of a gun!' Yet, as early as 1929, Mao also warned that, 'Our principle is that the party commands the gun, and the gun 
must never be allowed to command the party. ${ }^{14}$ Mao's edict actually obscured the organic party-army symbiosis - a condition that obtained until the 1980s when Deng Xiaoping and Yang Shangkun began to implement reforms that had the net effect of incrementally increasing the corporate autonomy and separate identity of the armed forces vis-à-vis the CCP. As a result of this symbiosis, the military came to the party's aid in suppressing civil unrest at several key junctures after 1949 (not the least of which during the Cultural Revolution). The CCP may have been born in the Shanghai underground and Jiangxi Soviet, but it had militarist parentage and was reared on the battlefield. Its formative years were spent at war, and it matured in a society with a strong militaristic tradition.

It was precisely because of this symbiotic relationship that the military never balked when instructed to maintain social order, suppress 'counter-revolutionaries,' arrest the Gang of Four, or perform other internal security duties. In other words, involvement by the army in 'political' affairs and domestic security was considered normal and legitimate, rather than a matter of intervention. This perspective also goes a long way towards explaining the PLA's role in the 1989 suppression of pro-democracy demonstrators and other citizens of Beijing, although the questioning by some senior military elites of this action and insubordination in the ranks at the time suggests the previous predominant identity of symbiosis had begun to give way to one of greater 'autonomy' of the armed forces vis-à-vis the Communist Party. Following the Tiananmen crackdown there was a renewed attempt by the party (and its constituent organs inside the PLA) substantially to increase control over, and ensure the loyalty of, the military. But this only lasted a year or two, and subsequently disparate signs of increased PLA 'autonomy' became apparent. As is discussed below, one dimension of this increased autonomy has been the tentative moves to increase state (i.e. government and legislative) control over the military, as distinct from party control. On the one hand, this does not mean that the longstanding party-army symbiosis is inert; nor, on the other hand, does it mean that a new era of a 'national army' (guomin jundui) or 'state army' (guojia jundui) has dawned. But recent changes do indicate that the interrelationship of party, army and state are in flux, and that the demands of 'professionalism' are redefining civil-military relations in China in directions more familiar in other modernizing nations. 


\section{The Impact of the Past on the Present}

This background has profound implications for understanding Chinese communist civil-military relations after the CCP came to power and in the present period. Scholars in PLA studies have devoted substantial analysis, and have had a lively discourse, on this issue in recent years. Unfortunately, this discussion has taken place almost entirely among PLA specialists, and has been largely sidelined to the periphery in the field of Chinese political studies. In this discourse Ellis Joffe has noted three schools of thought and lines of argument that have emerged over time: symbiosis, party control and professionalism. ${ }^{15}$ Too often analysts have juxtaposed these approaches whereas, as Joffe astutely notes, they should be viewed as complementary. These are not mutually exclusive categories of analysis. Professionalism has been an ongoing process since the 1950s and Marshall Peng Dehuai's tenure as Minister of Defence. Even under Marshall Lin Biao in the 1960s, and contrary to conventional wisdom, the military continued to professionalize and modernize in several dimensions. If there has been a tension, it has been between party control and limited military autonomy. While the norm of a symbiotic partyarmy relationship has been sustained over time, in different periods over the last 50 years (notably 1959-62, 1971-82 and 1989-92) the CCP has taken extra efforts to exert control over the armed forces, while at other junctures the military has sought to increase its corporate autonomy from the CCP. On several occasions the military sought to exert its role in the high-level party affairs (notably 1967, 1976, 1989 and to a certain extent in 1996), but it can be plausibly argued that this had more do with certain elites 'pulling' the military into politics during periods of social unrest and party weakness. ${ }^{16}$ In other periods (1954-59, 1974$75,1982-89)$ the armed forces have sought to increase their autonomy from the party, but this must be carefully distinguished as limited autonomy, as at no time has the PLA ever sought fully to separate itself from the CCP (or vice versa).

The military has simply sought greater autonomy over affairs it considers to be fully in its corporate domain - training, doctrine, force structure, personnel appointments, military education and protection of national security. Meanwhile, professional tendencies have been more or less persistent over time, although with a particular emphasis in the late-1950s, mid-1980s and late-1990s. The PLA has been, in Joffe's apt phrase, a 'party-army with professional characteristics'. ${ }^{17}$ Thus, the army's relationship with the party-state has evolved and fluctuated over time. Harry Harding has astutely noted that this fluctuation correlated 
as a function of the strength or weakness of the party-state. ${ }^{18}$ That is, during periods when the party-state was strong and the society stable, the military tended to act as a corporate bureaucratic lobby. When the party-state was weakened, the military tended to act either as a political arbiter between competing factions, support one faction against another, or intervene more broadly to stabilize society.

Joffe's characterization remains partially apt today, although since the mid-1990s we may have witnessed increasing military autonomy from the party in general, as well as nascent signs of increased state (i.e. government) control of the armed forces. ${ }^{19}$ This would suggest a slight variation on his typology: a more linear evolution from symbiosis to control to limited autonomy. This is discussed at greater length above and below, but suffice is to note here that increased state control need not imply, ipso facto, the zero-sum displacement of the party's relationship with the army. From one perspective, the relationship of the military to the state and party can be seen as complementary. That is, the state may be increasing its mechanisms of control and lines of authority over the armed forces, while the party withdraws to a more 'elevated' position. This has certainly been the case during the last decade in terms of the party-state relationship with respect to economic management, whereby the CCP sets forth the broader policy direction (fangzhen) while the state formulates more concretely the policy line (luxian) and implements specific policies (zhengce). The issue here is really one of relative autonomy and jurisdictional distinctions between institutional hierarchies and within functional policy spheres (which some political scientists refer to as the 'zoning of authority'). As the party has increasingly 'withdrawn' from its former totalistic and monopolistic influence over society and economy, greater 'space' and relative autonomy have been created for institutional and civic actors in China. While the tight symbiosis of party and army was forged early on, it is necessarily one of the last bonds to be broken in the reform process.

\section{The Changing Rules of Civil-Military Relations}

Since the 1990s the 'rules of the game' in civil-military relations in China have changed as a result of several developments:

- The institutional narrowing of the arenas of interaction (to the $\mathrm{CMC}$ );

- The more limited range of issues on which PLA leaders have a legitimate right to voice opinions, and their increasing reluctance to do so; 
- Increased professionalism in the senior officer corps and a concomitant decline in the promotion rates of officers with backgrounds as political commissars;

- A PLA desire to concentrate solely on issues of 'army building' and a generally non-interventionist approach to non-military issues;

- The creation of the PAP and concomitant disengagement of the PLA from internal security functions;

- An implicit bargain struck between Jiang Zemin and the PLA High Command that as long as he supports PLA budgets and professional goals, they will defer to his leadership status.

The 'rules of the game' have also been changed fundamentally as, for the first time, there now exist rules that define the military's functions and roles. These have been codified in several laws, documents and regulations in recent years. Their promulgation has been instrumental in advancing the twin goals of regularization (zhengguihua) and professionalization (zhiyehua) of the armed forces. The NPC has passed 12 laws and regulations, including: the National Defence Law, Military Service Law, Military Facilities Protection Law, Civil Air Defence Law, Reserve Officers Law, Hong Kong Special Administrative Region Garrison Law, Military Service Regulations, and Military Officers Ranks and Regulations. ${ }^{20}$ The State Council and CMC have jointly adopted 40-odd administrative laws and regulations, and the CMC has implemented 70-odd on its own, while individual PLA departments, service arms and military regions have formulated more than one thousand military rules and regulations. ${ }^{21}$ Taken together, the roles and functions of the PLA are now specified as never before.

The National Defence Law (NDL) has significant implications for civilmilitary relations. Adopted as law by the Fifth Session of the 8th National People's Congress in March 1997 and authorized by Presidential Decree No. 84, the National Defence Law is important for a number of reasons. ${ }^{22}$ The law went through five years of drafting and revision prior to its promulgation. This drafting process took place entirely within military legal circles, as co-ordinated by the Military Legal Office of the CMC. ${ }^{23}$

The NDL provides an overall framework for 'administering the army according to law' (yifa zhijun). The NDL elaborates in some detail various aspects of the armed forces organization, duties, 'construction' and legal responsibilities. It contains specific information about mobilization for war, maintenance of the armed forces during peacetime, leadership over the armed forces, the defence industrial and scientific establishment, military education and training, and many other aspects. 
These details are set forth in a lengthy document of 12 chapters and 70 articles. Associated publications interpret and spell out in further detail the content and meaning of the provisions of the NDL. ${ }^{24}$

Among these areas of importance, the NDL is particularly striking for one notable fact: the subordination of the military to the state. In Chinese the clear connotation of the term for state (guojia) is government, as distinct from the party. In China, this is operationalized to mean the State Council and its constituent ministries and commissions, the PRC President, as well as the National People's Congress (NPC). Beginning in the 1980s there was a conscious and deliberate attempt more clearly to demarcate the jurisdictional responsibilities of the CCP, State Council and NPC - particularly the policy of 'separating party from government' (dang-zheng fenkai) in economic policy-making and commercial management. Of course, this general process required the promulgation of numerous laws and regulations which had the cumulative effect of strengthening the NPC as a fourth institutional pillar of the PRC, along with the party, army and government. In the process, the NPC itself gained increased oversight functions vis-à-vis the government. State Council policies, budgets and appointments became at least nominally subject to legislative review by the NPC. However, the Communist Party as an institution has always insisted that it should police itself and its own membership, and this remains unchanged. This has included party members in the armed forces, who are subject to the CCP's Discipline Inspection Commission system. The CCP accordingly has its own constitution and its own 'election' procedures for its leadership. The party is clearly separated from the state. Its relationship to the armed forces has always been one of symbiosis and/or control. Certainly, the party has institutionally penetrated the military to ensure this relationship.

However, the 1997 National Defence Law suggests some fundamental departures in the relationship of the military to the party and state. In a number of its articles, and in several significant respects, the NDL clearly subordinates the 'armed forces' (which is defined as including the People's Armed Police, militia, and reserves) to the state. The term 'state' (guojia) is mentioned no fewer than 39 times in the law. Lest there be any ambiguity about the implications of this term, and the institutional subordination of the armed forces to state control, it is specified in some detail. Only in a single clause is the relationship of the army to the party mentioned (Article 19): 'The armed forces of the People's Republic of China are subject to leadership by the Communist Party, and $\mathrm{CCP}$ organizations in the armed forces shall conduct activities in accord- 
ance with the CCP constitution' (i.e. presumably with regard to party committees and discipline inspection work). Everywhere else in the NDL the military's subordination to the state is made abundantly clear, e.g.:

- (Article 5): 'The state shall exercise unified leadership over national defence activities.'

- (Article 7): 'The Chinese People's Liberation Army and the Chinese People's Armed Police shall carry out activities to support the government... .'

- (Article 10): 'The Standing Committee of the National People's Congress shall decide on the proclamation of a state of war and on general mobilization or partial mobilization in accordance with provisions of the constitution, and shall exercise other functions and powers in national defence as prescribed by the constitution.'

- (Article 11): 'The President of the People's Republic of China shall proclaim a state of war and issue mobilization orders in pursuance with the decisions of the National People's Congress and its Standing Committee... .'

- (Article 12): 'The State Council shall direct and administer the building of national defence and exercise the following functions and powers' (nine categories of responsibilities, including fiscal appropriation).

- (Article 13): 'The Central Military Commission shall direct the armed forces of the country and exercise the following functions and powers' (ten categories).

- (Article 14): 'The State Council and Central Military Commission may call co-ordination meetings according to circumstances to solve problems concerning national defence.'

In numerous other articles, the NDL stipulates responsibilities of the state for national defence matters. The absence of mention of the CCP is striking in this important law, which signals an important shift in civilmilitary relations.

The shift signalled in the NDL was explicated further in the 1998 National Defence White Paper. While the White Paper includes the single clause that 'Given the new historical conditions, the Chinese army upholds the absolute leadership of the CCP...,' greater emphasis is placed on the NPC, State Council and CMC as the institutions controlling the PLA, e.g.:

In accordance with the Constitution, the National Defence Law and other relevant laws, China has established and improved its national defence system. The state exercises unified leadership over defence-related activities. The NPC of the 
PRC is the highest organ of state power. It decides on questions of war and peace, and exercises other defence-related functions and powers provided for in the Constitution ... The State Council directs and administrates national defence work, and the CMC directs and assumes unified command of the nation's armed forces ... The active components of the PLA comprise the state's standing army ... The state exercises unified leadership and planned control over defence research and production. The State Council leads and administrates defence research and production, as well as defence expenditure and assets. The CMC approves the military equipment system of the armed forces and military equipment development plans and programs ... in co-ordination with the State Council, and manages defence outlays and assets jointly with the State Council. The state practises a state military supplies order system to guarantee the acquisition of weapons and other war materials. The state practises a financial allocations system for defence spending. It decides the size, structure and location of defence assets and the adjustment and disposal of these assets in accordance with the needs of national defence and economic construction. The State Council and CMC jointly lead mobilization preparation and implementation work. ${ }^{25}$ [emphasis added by author]

The adoption of the NDL provides evidence that the PLA is being placed increasingly under state control with the concomitant removal of party controls. To be sure, ambiguities remain. For example, it is unclear if references to the Central Military Commission mean the state or party CMC. This may be a moot point given that the membership composition of these two bodies is currently identical, although the language describing the CMC strongly suggests that its relationship to the armed forces is either one of joint administration with the State Council or merely 'line authority' to implement decisions, whereas broad decision-making authority seems to rest ultimately with the State Council, NPC Standing Committee and President of the republic. But, here, ambiguity exists insofar as Jiang Zemin concurrently holds the offices of President, CCP General Secretary, and CMC Chairman. Only when the President no longer heads the party but directs the CMC (as may occur in 2002 at the 16th Party Congress) will we know for sure that the partyarmy link has been fully severed. Another sign would be if the CMC were to become a body solely composed of military officers (similar to the Joint Chiefs of Staff) and the Minister of Defence were a civilian.

While one should have little doubt that the Chinese Communist Party and its leadership remain the ultimate source of political power and authority in China, it does seem clear that these steps taken in 1997-98 and subsequently are efforts to disentangle the military from party control. While the 1975 and 1978 national constitutions both explicitly subordinated the armed forces to the command of the CCP and its Chairman, that is no longer the case. Even much of the ambiguity of the early 
1990s is being clarified. ${ }^{26}$ Of course, it is difficult to determine the extent to which these reforms are taking root normatively and psychologically in the army, state and society. Interviews with PLA officers in the late-1990s still suggest substantial ambiguity over the issue of state versus party control. In fact, to many it remains a non-issue. When asked whether the armed forces are subordinate to the state or party, some officers have a puzzled look and respond, 'What do you mean? Of course, the PLA is loyal to the party! The party rules the country and the PLA defends it!' ${ }^{27}$ For many in the PLA, as this officer's response illustrates, the issue is precisely one of loyalty rather than constitutional control, and many still see the CCP as synonymous with the state and country! If orders came to defend the nation against an external opponent or enforce internal security, few officers or soldiers would question whether the order ultimately came from the CMC, State Council, NPC Standing Committee, PRC President or CCP General Secretary. While there have clearly been attempts to demarcate the parameters of authority between party, army and state by law, there still exists an essential fusion of the three - with ultimate party control - in the minds of most Chinese citizens. After 70 years of party control and symbiotic fusion between the three, it is not easy to redefine these interrelationships.

The continued ambiguity is also reflected in PLA publications and materials used by the General Political Department(GPD). Authoritative materials published to explain the new National Defence Law tend to emphasize the state's control over the armed forces, while GPD materials tend to take the opposite tack and emphasize party leadership.

The standard textbook used for 'political work' in the armed forces, published after the promulgation of the National Defence Law, is quite explicit about the CCP's relationship to the PLA. ${ }^{28}$ It states unambiguously:

The party's absolute leadership over the army is a fundamental feature of army building ... The CCP should be our army's only and independent leader and commander ... At no time can the CCP share authority over the military with other parties or organizations ... If the Communist Party loses its military authority, it will have no status ... Our army is an armed group to carry out the party's political tasks. ${ }^{29}$

The GPD volume is also explicit that the PLA is organizationally subordinate to the CCP Central Committee and Party's CMC. ${ }^{30}$ This runs in direct contradiction to the NDL and line of authority discussed above. Nowhere does the volume mention the role of state President, NPC, State Council, or state more generally. Perhaps most interesting is the extent to which the 'bourgeois' notion of state control of the armed forces is sharply criticized: 
Bourgeois liberal elements' advocacy of the military's "non-party-fication" (jundui feidanghua) is nonsense. In modern society there is no army that is not involved in politics and, essentially, there is no army not controlled by a ruling party. In Western capitalist countries, which practise the multi-party system, armies superficially do not belong to the party but to the state. But, in essence, it is a military that is led by the capitalist class and its ruling agents, the party ... Therefore, behind the state there are always capitalist parties that lead and command armies, and carry out capitalist dictatorship. Capitalist parties are never neutral in politics ... The basic content of this involvement is to oppress the proletariat and people's revolutions internally, and carry out invasion and expansion externally ... We must never allow ourselves to copy the Western capitalist countries' model, and never allow the excuse of the state's leadership over the army to deny the party's leadership over the army. Political work in our armed forces should criticize the absurd theory of a "non-party-fied army", and should emphasize and consistently insist on the absolute leadership over the army and ensure that our army is under the party's absolute leadership forever. ${ }^{31}$

In contrast, PLA materials used to explain the National Defence Law to troops take a very different approach by emphasizing state control. ${ }^{32}$ Unlike the GPD source above, this volume states unambiguously, 'National defence is one of the state's functions, and therefore the leadership and management of national defence is an important expression for state organs to realize their state functions. ${ }^{33}$ This volume explicates in 550 pages the various ways and justifications for state control over the military in China. It states that the head of state exercises 'commanding power over the armed forces,' but subsequently states that this 'commanding power' is 'exercised by the CMC Chairman'. ${ }^{34}$ This is not a problem at present as Jiang Zemin occupies both positions, but this has not historically always been the case (perhaps it is to indicate that the CMC Chairman and state President will henceforth be one and the same individual). It states clearly that the NPC Standing Committee is the 'highest organ of state power' and that the 'CMC is subordinate to the highest organ of state power,' but then confuses matters by stating that 'it is also subordinate to the CCP Central Committee. ${ }^{35}$ In a telling paragraph (that should not be surprising but makes mockery of efforts to separate and strengthen state power), the volume explains: 'Insisting on the party's leadership over the army is important in realizing the party's leadership over the state ... Due to historical reasons, the army is actually led by the Party's CMC.'36 The volume then goes on to define and justify various mechanisms that have been put into place to increase state supervision over various aspects of the military matters.

Discussions in the Chinese military media, such as the army newspaper Liberation Army Daily, also continue to indicate that the debate over party vs. state control of the armed forces remains alive. A sharp 
unsigned article in April 2001 attacked 'Western hostile forces that vigorously advocate the armed forces should be "separated from the party" (fei dang hua), "depoliticized" (fei zhengzhi hua) and "placed under the state" (guojia hua).' The article went on to add that, 'This is a corrosive agent that vainly attempts to weaken and do away with the CCP leadership and tries to disintegrate the soul of our armed forces, and is the great enemy of our party, state, and armed forces. ${ }^{.37}$

\section{Prospects for the Future}

Despite efforts to legislate and codify increased state/government authority over the PLA, the essential control by the CCP remains apparent (even if the symbiosis has become attenuated). If anything, there appears to be an ongoing struggle between the party and the state, but the winner is likely to be the military as it exerts increased autonomy from both.

Changes in the interrelationship of party, army and state in contemporary China must also be viewed in the context of emerging patterns of civil-military relations across Asia. With few exceptions (North Korea, Vietnam), civil-military relations in East, Southeast and South Asia have been fundamentally redefined in recent years in the process of democratization. In a number of countries that have known harsh authoritarian and military rule (South Korea, Taiwan, the Philippines, Indonesia, Thailand, Bangladesh and Pakistan), the armed forces have been removed from political power and influence, made accountable to sovereign legislatures, and returned to the barracks. Militaries in mufti have been replaced by democratically elected civilians. In all of these countries, the emasculation of political power and praetorian tendencies of the militaries has been a crucial element in establishing democratic institutions and rule. The trend in Asia follows that of Latin America and Africa.

The experiences of these countries, but particularly Taiwan, are suggestive for future civil-military relations in China. Thus far, the emerging literature on the process of democratic transition in Asia has paid relatively little attention to the civil-military dimension, ${ }^{38}$ although it is viewed as an important variable in the comparative literature. ${ }^{39}$ More comparative research needs to be done on Asian militaries and civilmilitary relations. ${ }^{40}$ Scholars of the PLA and Chinese politics need to place the recent changes in civil-military relations in the PRC outlined above in this broader regional context, while comparativists need to look more closely at the Chinese case. The current state of politics in the PRC certainly does not suggest that a creeping transition to democracy is silently taking place $^{41}$ as the CCP retains its grip on power. But, at 
the same time, we must not mistake the potential significance of the legislative efforts to subordinate the PLA to state control.

The Chinese case must also be placed in the comparative context of former socialist states led by communist parties. ${ }^{42}$ Broadly speaking, the experiences of the former Soviet and East European militaries suggest that professionalization and party control are by no means mutually exclusive, but in not a single case were these militaries consciously placed under state control via legislative means. Indeed in many cases, they fought (unsuccessfully) to save their ruling communist parties. ${ }^{43}$ The problem for the Chinese military has never been to subordinate itself to civilian authority, but rather to state control. Also, unlike the Soviet and East European experiences, the PLA has exhibited a long-standing tension between professionalization and attempts of politicization by the CCP. ${ }^{44}$

In these respects, the Chinese military is moving - or rather is being moved - into an entirely new era of civil-military relations and corporate professionalism. As such, one would surmise that the PLA will not shirk from the task of defending national security against external enemies - but will it do so again against internal enemies that may threaten the rule of the Communist Party? This will be the ultimate test of the redefined relationship of the army to the party and state in China.

\section{David Shambaugh is Professor of Political Science and International Affairs, and Director of the China Policy Program, at the George Washington University.}

\section{Notes}

* This paper draws and expands upon a chapter in my forthcoming bookModernizing China's Military: Progress, Problems \& Prospects (Berkeley and London: University of California Press, forthcoming 2002)

1 For further explorations on this topic see my 'Remaining Relevant: the Challenges for the Party in Late-Leninist China,' in David Finkelstein (ed.), China's New Leadership (Armonk, NY: M. E. Sharpe, forthcoming 2002).

2 This will be the subject of my forthcoming book Hanging On: the Chinese Communist Party since the Collapse of Global Communism.

3 For further elaboration of this concept see my 'Building the Party-State in China, 1949-1965: Bringing the Soldier back in,' in Timothy Cheek and Tony Saich (eds.), New Perspectives on State Socialism in China, 1949-65 (Armonk, NY: M. E. Sharpe, 1997).

4 This is also recognized by You Ji in his 'China: From Revolutionary Tool to Professional Military,' in Muthiah Alagappa (ed.), Military Professionalism in Asia:Conceptual and Empirical Perspectives (Honolulu: East-West Center, 2001), pp. 111-36.

5 The classic typology is, of course, Samuel P. Huntington, The Soldier and the State: The Theory and Politics of Civil-Military Relations (Cambridge, MA: Harvard University Press, 1957). Also see Morris Janowitz, The Professional Soldier (New York: The Free Press, 1960).

6 The pertinent literature here is extensive. See, for example, Timothy Colton and Thane Gustafson (eds.), Soldiers and the State (Princeton: Princeton University Press, 1990); Abraham F. Lowenthal and Samuel J. Fitch (eds.), Armies and Politics in Latin America (New York: 
Holmes \& Meier, 1986); Alfred Stepan, Rethinking Military Politics (Princeton, NJ: Princeton University Press, 1988); Viberto Selochan, The Military, the State, and Development in Asia and the Pacific (Boulder, CO: Westview Press, 1991); Amos Perlmutter, The Military and Politics in Modern Times (New Haven, CT: Yale University Press, 1977); Eric A. Nordlinger, Soldiers in Politics (Englewood Cliffs, NJ: Prentice-Hall, 1977); Catherine M. Kelleher (ed.), PoliticalMilitary Systems (Beverly Hills, CA: Sage Publications, 1974).

7 This sub-field has also generated a substantial, if somewhat dated, literature. See, for example, Dale Herspring and Ivan Volges (eds.), Civil-Military Relations in Communist Systems (Boulder, CO: Westview Press, 1978); Jonathan Adelman (ed.), Communist Armies in Politics (Boulder, CO: Westview Press, 1982); Dale R. Herspring, Russian Civil-Military Relations (Bloomington: Indiana University Press, 1996); Kenneth M. Currie, Soviet Military Politics (New York: Paragon Press, 1991).

8 See Larry Diamond and Marc F. Plattner (eds.), Civil-Military Relations and Democracy (Baltimore: The Johns Hopkins University Press, 1996).

9 Monte Bullard, The Soldier and the Citizen: The Role of the Military in Taiwan's Development (Armonk, NY: M. E. Sharpe, 1997); Cheng Hsiao-shih, Party-Military Relations in the PRC and Taiwan (Boulder, CO: Westview Press, 1990); Bruce J. Dickson, Democratization in China and Taiwan: The Adaptability of Leninist Parties (Oxford: Clarendon Press, 1998); David Shambaugh, 'Taiwan's Security: Maintaining Deterrence amidst Political Accountability,' in David Shambaugh (ed.), Contemporary Taiwan (Oxford: Clarendon Press, 1998); Lu-Hsun Hung, 'Observations on Civilian Control of the ROC Armed Forces Following the Passage of Two Laws Concerning National Defense,' Taiwan Defense Affairs, vol. 1, no. 2 (Winter 2000/01), pp. 7-38; and Chin-chiang Su and Ming-shih Shen, 'Taiwan's Political Warfare System and Civil-Military Relations,' Taiwan Defense Affairs, vol. 1, no. 2 (Winter 2000/01), pp. 39-64.

10 Recent efforts to do this are Thomas Bickford, 'A Retrospective on the Study of Chinese Civil-Military Relations since 1979: What Have We Learned, Where Do WeGo?;' and David Shambaugh, 'Commentary on Civil-Military Relations in China: The Search for New Paradigms,' in James C. Mulvenon and Andrew N. D. Yang (eds.), Seeking Truth from Facts: A Retrospective on Chinese Military Studies in the Post-Mao Era (Santa Monica, CA: The Rand Corporation, 2001).

11 Hans van de Ven, 'The Military in the Republic,' The China Quarterly, no. 150 (June 1997).

12 David Shambaugh, 'The Soldier and the State in China: The Political Work System in the People's Liberation Army,' in Brian Hook (ed.), The Individual and the State in China (Oxford: Clarendon Press, 1997); Harlan Jencks, From Muskets to Missiles: Politics and Professionalism in the Chinese Army, 1945-1981 (Boulder, CO: Westview Press, 1982), chapters 1-3.

13 This assertion does not obviate the important roles played by land reform and nationalism.

14 Mao Zedong, 'Problems of War and Strategy,' Selected Works of Mao Zedong, vol. II (Beijing: Foreign Languages Press, 1975), p. 224.

15 Ellis Joffe, 'Party-Army Relations in China: Retrospect and Prospect,' in David Shambaugh (ed.), China's Military in Transition (Oxford: Clarendon Press, 1997). Interestingly, this typology mirrors the debates among scholars of civil-military relations in the former Soviet Union. Albeit in a different context, Timothy Colton articulated the symbiosis thesis, Roman Kolkowitz the control thesis, and William Odom the autonomy thesis.

16 See Ellis Joffe, The Military and China's New Politics: Trends and Counter-Trends (Taipei:Chinese Council on Advanced Policy Studies, CAPS Papers, no. 19, 1997).

$17 \mathrm{Ibid}$. In his landmark study, Harlan Jencks tends to juxtapose the two as he argues that, 'Chinese officers, especially those below corps level, are strongly disinclined toward political involvement.' See Jencks, From Muskets to Missiles, p. 255.

18 See Harry Harding, 'The Role of the Military in Chinese Politics,' in Victor Falkenheim (ed.), Citizens and Groups in Contemporary China (Ann Arbor: University of Michigan Center for Chinese Studies, 1987), pp. 213-56. 
19 Many analysts are dubious that this process is underway, and some-such as Jeremy Paltiel - believe it to be a false dichotomy. Paltiel asserts that 'the Chinese armed forces have never faced a choice between loyalty to the state and obedience to the party.' See Jeremy Paltiel, 'PLA Allegiance on Parade: Civil-Military Relations in Transition,' The China Quarterly, no. 143, September 1995. Paltiel is correct in this observation, but I would argue that increasing state authority and control over the armed forces does not ipso facto imply a zero-sum displacement of the party's relationship with the army. They may be seen as complementary.

20 See Thomas A. Bickford, 'Regularization and the Chinese People's Liberation Army: An Assessment of Change,' Asian Survey (May/June 2000), pp. 456-74.

21 China's National Defence (Defence White Paper), issued by the Information Office of the State Council, (July 1998).

22 For an excellent evaluation of the National Defence Law, see Samantha Blum, 'The National Defence Law of China - the Dragon's head of Military Law,' unpublished paper (May 2001).

23 Interview with Sr. Col. Zhu Jianye and Sr. Col. Shen Qiuchao of this office (April 1999).

24 The most important of these is Xu Jiangrui and Fang Ning, Guofangfa Gailun [Survey of the National Defense Law] (Beijing: Junshi kexue chubanshe, 1998).

25 Ibid, pp. 15-17 (English edition).

26 For excellent and learned discussions of the legalities during this period see Jeremy Paltiel, 'PLA Allegiance on Parade' and 'Civil-Military Relations in China: An Obstacle to Constitutionalism?,' The Journal of Chinese Law, (September 1995), pp. 35-65.

27 Interview with Academy of Military Sciences officer, (September 1998).

28 National Defence University Party History and Party Building Research Office (ed.), Zhongguo Renmin Jiefangiun zhengzhi gongzuoxue [A Study of Political Work in the Chinese People's Liberation Army] (Beijing: National Defence University Press, 1998).

29 Ibid, pp. 197-98.

30 Ibid, pp. 198-200.

31 Ibid, pp. 203-04.

$32 \mathrm{Xu}$ Jiangrui and Fang Ning, Guofangfa Gailan.

33 Ibid, p. 114.

34 Ibid, pp. 122-23.

35 Ibid, p. 118.

36 Ibid.

37 No author, 'Clearly Understanding the Essence of "Separating the Armed Forces from the Party, "Depoliticizing Them", and "Placing Them under the State",' Jiefangjun bao, 18 April 2001, in FBIS-CHI, 18 April 2001.

38 See Larry Diamond and Marc F. Plattner (eds.), Democracy in East Asia (Baltimore: Johns Hopkins University Press, 1998); and Diamond, Plattner, Yun-han Chu and Hung-mao Tien (eds.), Consolidating the Third Wave Democracies (Baltimore: Johns Hopkins University Press, 1997).

39 See Diamond and Plattner, Civil-Military Relations and Democracy.

40 For a significant effort in this direction see Muthiah Alagappa (ed.), Coercion and Governance: The Declining Role of the Military in Asia (Stanford, CA: Stanford University Press, 2001).

41 For one view to the contrary see Minxin Pei, '“Creeping Democratization" in China,' in Diamond, Plattner, Chu and Tien (eds.), Consolidating the Third Wave Democracies, pp. 21327.

42 To be sure, there is no small literature in this field. See the sources noted in footnote 13.

43 See Gerald Segal and John Phipps, 'Why Communist Armies Defend Their Parties,' in Richard H. Yang (ed.), China's Military: The PLA in 1990/91 (Kaohsiung: National Sun Yatsen University, 1991), pp. 133-44.

44 In the large literature on this subject, see in particular Harlan Jencks, From Muskets to Missiles. 